\title{
MAPPAMMANA TRADITION OF BUGINESE COMMUNITY IN BONE: A LEGAL REVIEW OF ISLAMIC INHERITANCE
}

\author{
Nurul Wakia \\ Lecturer at Faculty of Shariah and Law of UIN Alauddin Makassar \\ Email: nurulwakia42@gmail.com
}

\begin{abstract}
The mappammana tradition is a custom of the Buginese community in Bone as a form of transfer of properties from the heir to the heirs. Mappammana is a system of inheritance that has been practiced in the past to this day. The mappammana mechanism is an interesting issue, because in the millennial era, this system is still used by the Buginese community in Bone in the transfer of properties. It is important to explain the connection of the mappamana tradition in the frame of Islamic inheritance law.Research is a field of research, data sources obtained from interviews with religious leaders and figures of the Buginese community in Bone. The approach used is theological normative, sociological, and anthropological by examining the social phenomenon of the mappaammana system of the Buginese community in Bone. The findings of this study indicate that there are mappammana traditions that are general namely, pabbere and pappaseng, are gifts without any sacred value contained in the object used as maanaa.As for the mappammana, it is 'ampīkâle', specifically applies because ampik âleis a sacred gift and is accompanied by a will. Based on Syahrur's hudud theory, at-Tufi's Maslahah, and al-Jauziayah's urf theory, mappammana as a legacy system practiced by the Buginese community in Bone is considered in line with the values of the Islamic inheritance system because it still upholds the values of consensus value and benefit. The implication of this finding is that the distribution of inheritance does not look at the way it is, but the most important thing is the pleasure of the parties in accepting the results of deliberations and distance from disputes between fellow heirs.

Tradisi mappammana merupakan adat masyarakat Bugis Bone sebagai bentuk peralihan harta pewaris kepada ahli warisnya. Mappammana adalah sistem peralihan kewarisan yang dipraktekkan dimasa lampau hingga sekarang. Mekanisme mappammana menjadi isu yang menarik, karena di era milineal sistem ini masih digunakan oleh masyarakat Bugis Bone dalam peralihan harta. Maka penting untuk dijelaskan koneksi tradisi mappamana dalam bingkai hukum kewarisan Islam. Penelitian merupakan field research, sumber data diperoleh dari hasil wawancara terhadap tokoh agama dan tokoh masyarakat Bugis Bone. Pendekatan yang digunakan adalah teologis normatif, sosiologis, dan antropologis dengan menelaah fenomena sosial sistem mappaammana dalam masyarakat Bugis
\end{abstract}


Bone. Temuan penelitian ini menunjukkan bahwa taradisi mappammana ada yang bersifat umum yaitu, pabbere dan pappaseng, merupakan pemberian tanpa ada nilai sakral yang terkandung dalam objek yang dijadikan sebagai maanaa. Adapun mappammana bersifat ampīkâle, berlaku secara khusus karena ampīkâle merupakan pemberian yang sakral dan disertai dengan wasiat. Berdasar pada teori hudud-nya Syahrur, Maslahah-nya at-Tufi, dan teori urf-nya al-Jauziayah, maka mappammana sebagai sistem kewarisan yang dipraktekkan masyarakat Bugis Bone dianggap sejalan dengan nilai-nilai sistem kewarisan Islam karena tetap menjunjung tinggi nilai-nilai mufakat dan kemaslahatan. Implikasi temuan ini, bahwa dalam pembagian warisan tidak melihat dari caranya, akan tetapi terpenting adalah keridhoan pihak-pihak dalam menerima hasil musyawarah dan menjauhkan dari persengketaan antara sesama ahli waris.

Keywords: Islamic Inheritance Law; Tradition; Mappammana; Buginese in Bone.

\section{INTRODUCTION}

The inheritance legal system in Islam is a reference in transferring property of the deceased to the heirs. In detail the inheritance problem has been described by Allah in the Holy Qur'an, for example the division of inheritance of men and women, either little or much according to the part that has been determined. ${ }^{1}$

Normatively, in the Qur'an Surah An-Nisâ/4: 7 has illustrated that male and female heirs have the right to inherit the inheritance of their parents, relatives whose part is determined in the Qur'an. This stipulation becomes an obligation for Muslims to be implemented and practiced in life. ${ }^{2}$ The Qur'an has outlined heirs who are entitled to a certain portion as stipulated in the Sharia called zâwi al-furv̄d.

In Islamic inheritance law, it is known as the principle of ijbâri, which requires the distribution of property of people who have died to their heirs. Transfer of property is a matter that is studied in Jurisprudence, ideally all the inheritance system provisions contained in the Qur'an must be obeyed by Muslims in the regulation and transfer of inheritance property. The provision aims to avoid disputes between heirs after the heir dies, ${ }^{3}$ and keep away from disputes that cause rift relations among family members. ${ }^{4}$

\footnotetext{
${ }^{1}$ See Qur'an Surah An-Nisâ/4:7, inal-Mehri, A. B. (Ed.). The Qur'ān: With Sūrah Introductions and Appendices: Saheeh International Translation (Maktabah Booksellers and Publishers, 2010), p. 101.

${ }^{2}$ Muhammad Ali Ash-Shabōni, Al-mawaris FisySyari'ati Islâmiyyah'ala dhau' Al-kitâb was sunnah translated by: A. M. Baslamah, Pembagian Waris Menurut Islam (Jakarta: Gema Insani Press, 1996), p. 46.

${ }^{3}$ Amir Syarifuddin, Garis-Garis Besar Fiqh (2 ${ }^{\text {nd }}$ Ed.; Jakarta: Prenada Media, 2005), p. 148.

${ }^{4}$ Suhrawardi K. Lubis and Komis Simanjuntak, Hukum Waris Islam (Jakarta: Sinar Grafika, 2008), p. 1.
} 
In practice, sometimes problems arise over the distribution of properties that cannot be solved based on Islamic inheritance law, so that people take solutions that bring together benefits. This is because, among the community groups, there are those who cannot accept the provisions of two (male) to one (female) as stipulated in the Qur'an.This attitude causes the distribution of inheritance among the community often causes disputes within the family, especially the determination of who has the right to receive and the amount of inheritance to be obtained. Not infrequently among the heirs feel that the process of distribution of inheritance is not fair so it demands more parts. This is what often causes a relationship breakdown in the family. ${ }^{5}$

In fact, it often creates a radical attitude by justifying various ways to obtain the inheritance. Such facts, commonly found in people's lives and have existed in the history of mankind, until now. ${ }^{6}$ Another reason for not implementing Islamic inheritance law could be due to the lack of public knowledge about the rules of Islamic inheritance law, ${ }^{7}$ so that in the practice of inheritance it is very common to be resolved by local customary law.

For most of the Indonesian people, customary law is always upheld and used as a basis for making decisions regarding issues of daily life. Compliance also applies in matters of inheritance. Until now some of Indonesian population still maintain customary law in managing the distribution of inheritance.As in the Islamic inheritance legal system, the customary inheritance system also recognizes the principle of individuals that allows heirs to obtain inheritance individually. Thus, every heir will get the right of inheritance in accordance with predetermined parts. ${ }^{8}$ This provision is followed in accordance with the division of customary law in each area.

Among the Buginese community in Bone, for example, there is a tradition of inheritance that was carried out when parents were still alive, known as mappamana. The process of distribution, women get a greater share when compared to men. The heirs who get more inheritance are children who will take care of and live with their parents when they are old.In general, the custom of Buginese community in Bone is that parents choose to live with their daughter when they are

${ }^{5}$ Amin Husein Nasution, Hukum Kewarisan:Suatu Analisis Komparatif Pemikiran Mujtahid dan Kompilasi Hukum Islam (3 ${ }^{\text {rd }}$ Ed.; Jakarta: Rajawali Pers, 2014, p. 52.

${ }^{6}$ Ira Hasnita and Asni Zubair, Tinjauan Hukum Islam terhadap Ampikale dalam Sistem

Kewarisan Masyarakat Buginese, Al-Syakhshiyyah Jurnal Hukum Keluarga Islam dan Kemanusiaan,Vol. 1, Number 2, 2019.

${ }^{7}$ Asni Zubair, Aktualisasi Hukum Kewarisan Islam (Studi tentang Kesadaran Hukum Masyarakat di Desa Wollangi Kec. Barebbo terhadap Hukum Kewarisan Islam), Al-Risalah Jurnal Hukum Keluarga Islam (Akhwal al-Syaksyiah), Vol. 3, 2017.

${ }^{8}$ Imam Muchlas, Waris Mewaris dalam Islam (Pasuruan: Garoeda Buana Indah, 1996), p. 84. 
old. The consideration is that it is the daughter who is more often at home and more loyal and has greater affection for her parents.

This tradition has been valid since the ancestors of the Buginese community in Bone, which seems to be still maintained in people's lives. The inheritance system is considered as a recognition in life that is not only practiced in the past but in the present Buginese community in Bone still adheres to it. ${ }^{9}$ Therefore, this article will discuss about the mappammana tradition in the view of Islamic inheritance law. This is to provide factual answers to the correlation between tradition and texts. In addition, to provide a philosophical interpretation of the value of the transfer of property with mappammana with the transfer of property based on Islamic inheritance law.

\section{METHODOLOGY}

This study is a field research (data research) whose data are obtained from interviews with community leaders and religious leaders who are considered to understand the mappamana system. This research was conducted in Bone Regency because in general, the Buginese community in Bone is still thick with the tradition of transfer of property with mappammana system. The approach used is theological normative, sociological, and anthropological by examining the social phenomenon of the mappaammana system in the Buginese community in Bone. Efforts to review the data obtained from the field, the data were analyzed qualitatively beginning with data reduction, data presentation, verification and conclusion drawing.

\section{DISCUSSION}

\section{A. Conception of Mappammana in the Buginese Bone Tradition}

The Mappammana system is a transfer of property by heirs, both living and dead, to children or relatives who are made as heirs. Thus, the mappammana process in the Buginese community in Bone is sometimes carried out by living parents by gathering all of their heirs to be shared, or when the parents have passed away. When the mappammana process is carried out by parents after death, it is usually accompanied by a will that is surrendered and entrusted to the family or elder relatives.Some of the inheritance is for funerals, to pay off debts and to fulfill a will. If all matters relating to the necessity and obligations of the deceased have been completed, the inheritance will be distributed to the heirs. This means that the mappammana system in the Buginese community in Bone is still paying attention to the need for holding a corpse. The remaining assets from the process of organizing

${ }^{9}$ Muh. Sabri, Persepsi Hukum Islam terhadap Sistem Kewarisan Berbasis Budaya pada Masyarakat Buginese Bone, Al-Risalah Jurnal Hukum Keluarga Islam (Akhwal al-Syaksyiah), Vol. 3, 2017. 
the remains were distributed to the heirs.

The nasab system or descendants in the Buginese Bone customary inheritance law still provide space for male and female descendants to inherit from their parents and relatives. However, not all assets can be shared, the house and furniture in it along with the jewelry will be given to the female heirs. If the heirs of two or more women, the woman can occupy the house, while the men immediately leave the house. However, in the case of mappamana, it is very dependent of the heirs, in this case the parents who will share their heirs, usually in general, all heirs, both men and women, will get the fair distribution. ${ }^{10}$

The tradition of separating houses and jewelery is a custom of the Buginese community in Bone, which was adopted from generation to generation since previous ancestors, with the consideration that it is women who will look after their parents in their old age. The Buginese Bone community, is a society known for its obedience to religion, but at the same time holds fast to the customs that have been passed down through generations in its life. In general, the Buginese community in Bone divided the inheritance into several ways, including:

\section{Grant(Pabbere)}

Pabbereis a gift given by parents when they are still alive, given to people who are considered to have an inheritance relationship with him/her. ${ }^{11}$ Pabbereis a certain legal act of someone who gives wealth to another person (still has an inheritance relationship), according to applicable legal rules. ${ }^{12}$ The purpose of Pabbere carried out while the heir was still alive was to avoid disputes between heirs after the heir died. The Buginese Bone tradition in conducting aqad giving (nabbereang) from parents to children is done in two ways:

\section{(a) Pabberethat applies in general}

The Buginese Bone tradition of implementing a grant contract (pabbere) by means of tudang sipulung, namely deliberation of all heirs and village government or traditional leaders as witnesses. The decision is fully up to the parents who want to provide the grant. ${ }^{13}$ Pabbere from parents to children is a habit that is often found in the Buginese community in Bone in the process of transferring assets. Parents' compensation is done by giving assets to the heirs with a sincere intention so that the assets are managed properly by their children.

The basis of pabbere is contained in the buginese proverbial luka maanaa telluka pabbere. This means that maanaa may be taken back when the parents' mood

\footnotetext{
${ }^{10} \mathrm{~A}$. Yushan, Bone customs figure, Interview, WatamponeAugust $3^{\text {rd }}, 2019$.

${ }^{11}$ A. Baso Bone, Bone customs figure, Interview, Watampone, November $5^{\text {th }}, 2019$.

${ }^{12} \mathrm{H}$. Rapi, Bone customs figure, Interview, Lompo, November $10^{\text {th }}, 2019$.

${ }^{13}$ A. Yushan, Bone customs figure, Interview, Watampone, August $3^{\text {rd }}, 2019$.
} 
is shaken or there is a dispute with the child who is given maanaa, while pabbere once given cannot be withdrawn. ${ }^{14}$ This explanation shows that pabbere (grant) is different from maanaa (inheritance). The initial meaning of pabbere is permanent and must not be contested, pabbere is different from maanaa. All heirs are entitled to pabbere, whether married or not, but the decision is absolutely left to the parents to whom among the heirs will be given. ${ }^{15}$

Therefore, there may be those who get pabbere from among the heirs. However, the position of pabbere as a gift from parents to their children should not be excessive, resulting in not fulfilling the rights of other heirs. Pabbere that applies in general is pabberefrom parents to heirs who are not accompanied by a certain will and the goods given do not contain sacred values in the family tradition. ${ }^{16}$ This shows that pabbere, which is generally accepted, can be given to any heirs because the goods given do not contain sacred values in the family tradition. In addition, this kind of pabbere is usually not accompanied by a message from the heir.

\section{(b) Ampīkâle}

Between parents and their heirs there is something called ampikâle. In the Buginese tradition in Bone, ampikâle is a pabbere which is sacred in nature and is accompanied by a will (pappaseng), so it is given to the heirs who are very useful to their parents (pabberelao rianak iya mampiri aleku). ${ }^{17}$ It is said that it is sacred because the goods to be given are obtained from the proceeds of the gift from the ancestors who have been passed down from generation to generation for the services of their parents (iya mampīri taumatuakku), so that not all children can ampīkâle even though it is possible for all children to be gifted as a gift from their parents. Among the wills uttered by parents when giving ampīkâle to their children is "âja mupakkuai sangadi nanrepi âpi pale' jarimmu", meaning that you should not sell this item unless you are in a state of urgency. ${ }^{18}$ This shows that the item given as ampkle is a very valuable item for the heir, even though the nominal value may not be too expensive. In a state of urgency, these items may be sold if they are purchased by people who are related to them.

\section{A Will (Pappaseng)}

A will or pappaseng is a message that contains the final will of the person

\footnotetext{
${ }^{14}$ A. Yushan, Bone customs figure, Interview, Watampone, August $3^{\text {rd }}, 2019$.

${ }^{15} \mathrm{H}$. Abd. Jabbar, PPN Assistant in Bajoe, Interview, Bajoe, January $12^{\text {th }}, 2020$.

${ }^{16}$ A. Yushan, Bone customs figure, Interview, Watampone, August $3^{\text {rd }}, 2019$.

${ }^{17}$ A. Yushan, Bone customs figure, Interview, Watampone, August $3^{\text {rd }}, 2019$.

${ }^{18} \mathrm{~A}$. Yushan, Bone customs figure, Interview, Watampone, August $3^{\text {rd }}, 2019$.
} 
who will pass away regarding the transfer of property left behind by determining certain parts for his heirs. Pappaseng is made before the heir dies, but the transfer of the inheritance is carried out according to the person who gives the paseng, the embodiment of the paseng must be attended by the heirs and the close family of the giver ofpaseng. ${ }^{19}$ Pappaseng is also a way for parents to convey their final wishes regarding the distribution of assets that will be left behind and only take effect after the paseng giver dies. ${ }^{20}$ The purpose of pappaseng is to prevent potential disputes between heirs. ${ }^{21}$

Pappaseng as pabbere is only a process of transferring property among the heirs. The heir remains obedient to the provisions, all heirs receive a fair share, they may not eliminate the rights of a single child, but parents have the right to determine the assets to be given to the heirs. ${ }^{22}$ This is intended to prevent disputes between the heirs. ${ }^{23}$

\section{Maanaa}

The customary law tradition of Buginese Bone does not stipulate when the property can be distributed to the heirs. based on the custom of the distribution of assets after the heir dies, it is carried out after the matt accommodated on the seventh day, fortith day, the hundredth day after the heir dies because at that time the heirs usually still gather. ${ }^{24}$

The Buginese Bone community already has various unwritten rules regarding traditions related to the term mappamana. Among them are provisions regarding inheritance transfer, for example pabbere is a gift, pappaseng is a will, and inheritance is known as bicara maanaa. ${ }^{25}$ As previously explained, the three provisions differ from one another, but are substantially the same, because, the objects are both talking about the transfer of property to the heirs.

The element of Bicaramaanaa in Buginese community in Bone is, heirs who will transfer their assets, heirs who will get the right of transfer and inheritance as objects or items to be transferred ownership. ${ }^{26}$ The inheritance consists of the inheritance of the "warang parang siwali" and the assets obtained together with the "warang parang bali reso" between husband and wife. ${ }^{27}$

\footnotetext{
${ }^{19}$ A. Baso Bone, Bone customs figure, Interview, Watampone, November $5^{\text {th }}, 2019$.

${ }^{20} \mathrm{H}$. Rapi, Customs figure, Interview, Lompo, November $10^{\text {th }}, 2019$.

${ }^{21}$ A. Yushan, Bone customs figure, Interview, Watampone, August $3^{\text {rd }}, 2019$.

${ }^{22}$ A. Yushan, Bone customs figure, Interview, Watampone, August $3^{\text {rd }}, 2019$.

${ }^{23}$ H. Rapi, Customs figure, Interview, Lompo, November $10^{\text {th }}, 2019$.

${ }^{24}$ A. Yushan, Bone customs figure, Interview, Watampone, August $3^{\text {rd }}, 2019$.

${ }^{25}$ A. Yushan, Bone customs figure, Interview, Watampone, August $3^{\text {rd }}, 2019$.

${ }^{26}$ A. Yushan, Bone customs figure, Interview, Watampone, August $3^{\text {rd }}, 2019$.

${ }^{27}$ A. Yushan, Bone customs figure, Interview, Watampone, August $3^{\text {rd }}, 2019$.
} 
Waramparang siwali is only given by the heirs who own the property. While waram parang balireso is separated first between the husband and the wife part. Each part is given to the heirs of the husband and wife. The division in maanaa speech is not only based on the exact same amountbut is based on a balance between all heirs. This method of division is different from the division of Islamic inheritance law and Western inheritance law. ${ }^{28}$ Before the heirs gather, sometimes the inheritance is managed first by a widow or widower, and the part of the immature child is managed by the eldest son.

\section{B. Mappamana Tradition in Islamic Inheritance Law}

In Islam, the branch of science that talks about inheritance law is family law. The branch of science that deals with inheritance is the faraid science linked to the transfer of inherited property, the calculation of the portion of each heir and the distribution of the inheritance to his heirs.

The Buginese Bone community adheres to the lineage of both parents, in terms of dividing the inheritance between men and women, they are entitled to a share of the parents. ${ }^{29}$ This inheritance characteristic is called parental based on the individual principle which allows each heir to be entitled to inheritance from his parents. This model of inheritance is also embraced by the Buginese community in Bone, known as mappamana.

The assets that are made into maanaa in the Buginese Bone tradition are usually in the form of land, rice fields and houses which are divided equally between sons and daughter. ${ }^{30}$ This is done to avoid disputes between the heirs due to the imbalance of their respective parts. Especially for unmarried daughters, they have the right to occupy the house. When they have a husband, the house is divided based on mutual agreement with all the heirs.

However, there are still some among the Buginese community in Bone who practice the inheritance law based on the Holy Qur'an, where men get two parts while women get one part.In line with the Buginese proverb, majjujung makkunraie mallempa aroanae, meaning that the burden of a man is heavier because it will provide for his wife and children. Whereas in the mappammana tradition, the distribution of inheritance is not a problem if it is divided equally among all heirs left by the heir without distinguishing between men and women.

The compilation of Islamic Law in Article 176 regulates the division between male and female. If the female herself gets half, and when two or more

\footnotetext{
${ }^{28}$ Ibnu Qoyim, Adat dan Agama aalam Perkawinan dan Kewarisan pada Masyarakat Buginese(Jakarta: (PMB) LIPI, 2005), p. 118.

${ }^{29}$ A. Baso Bone, Bone customs figure, Interview, Watampone, November $5^{\text {th }}, 2018$.

${ }^{30}$ A. Baso Bone, Bone customs figure, Interview, Watampone, November $5^{\text {th }}, 2018$.
} 
females get the two-thirds share and if the females is together with the male, then the male gets two portions while the female gets one portion. ${ }^{31}$

Among those who reject the KHI argue that the division of inheritance from two to one has the potential to create a sense of injustice towards women. In the present era, it is not only the husband who makes a living, but in certain cases, women also take part in earning a living, sometimes being far more advanced than men. If this condition is still applied, the concept of the $2: 1$ division is still applied, it is considered a form of injustice. ${ }^{32}$ As for the basis for stipulating the proportion of men that are greater than women, the Qur'an Surah an-Nisâ/4: 11.

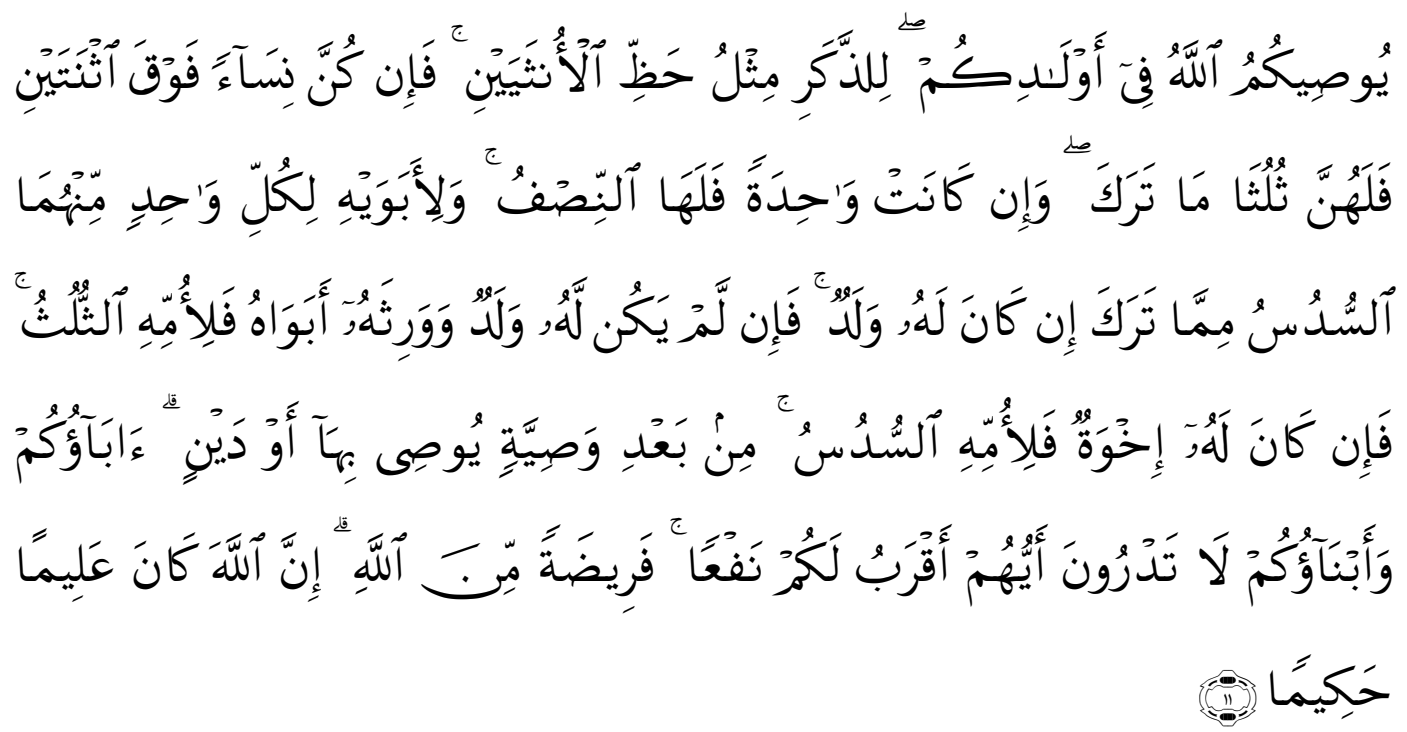

The translation:

Allah instructs you concerning your children: for the male, what is equal to the share of two females. But if there are (only) daughters, two or more, for them is two thirds of one's estate. And if there is only one, for her is half. And for one's parents, to each one of them is a sixth of his estate if he left children. But if he had no children and the parents (alone) inherit from him, then for his mother is one third. And if he had brothers (or sisters), for his mother is a sixth, after any bequest he (may have) made or debt. Your parents or your children - you know not which of them are nearest to you in benefit. (These shares are) an obligation (imposed) by Allah. Indeed, Allah is ever Knowing and Wise. ${ }^{33}$

There is a difference of opinion about the word فَوْقَ أثنَتَتْنِ which is entitled to share two thirds whether two people or three people and above. According to al-

\footnotetext{
${ }^{31}$ Abdurrahman, Kompilasi Hukum Islam (Jakarta: Akademika Pressindo, 2007), p. 157.

${ }^{32}$ Sabriadi HR, Dosen IAIN Bone, Interview, Bajoe, January 20 ${ }^{\text {th }}, 2020$.

${ }^{33}$ al-Mehri, A. B. (Ed.). The Qu''ān: With Sūrah Introductions and Appendices: Saheeh International Translation (Maktabah Booksellers and Publishers, 2010), p. 101.
} 


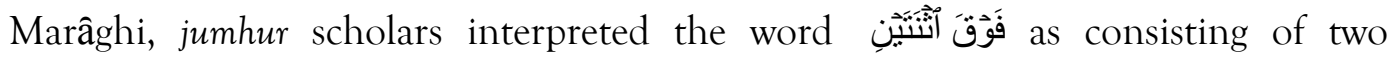
daughters. ${ }^{34}$ Muhammad Syahrur in his hudud theory (had al a'lâ wa had al adnâ, meaning the minimum and maximum limits) in the Qur'an Surah An-Nisa/4: 11, if the family economy is borne by the husband, and the wife is not involved at all, then the law of Allah can be practiced, namely two parts for men and one part for women.In terms of percentage, men get a minimum share of $66.6 \%$. If a boy gets $75 \%$ while a girl gets $25 \%$ then it violates the limits of the decree of Allah. If men get $60 \%$ and $40 \%$ of women, it means that they do not violate the boundaries of Allah's law because they are still within the limits of Allah's law. In this situation, the taking of ijtihad may also apply the principle of approaching between the two imposed minimum and maximum limits, so as to obtain a balance between the two, namely that between men and women each receiving 50\%.Such principles are based on conditions and situations of inheritance or developments in historical settings, or on the consideration of both at once. ${ }^{35}$ This is based on the principles of fiqh al-dharuratul yuzallu, which means that fading must be eliminated. ${ }^{36}$

All decisions that have the potential to cause harm without good reasons must be eliminated. For example, in a situation where the distribution of inheritance causes problems between family members, such as disputes over the share of each heir, then the distribution process takes precedence which brings more benefits and avoids faltering. This is where the mappammana system can be applied in the inheritance distribution process.

In line with Syahrur's opinion, according to Najamuddin at-Tufi in an effort to reform Islamic law, including whether or not the mappammana system can be carried out in inheritance practice, it is necessary to make a basis for consideration is the concept of maslahah (goodness or benefit in a legal product).Based on textual evidence, at-Tufi describes his maslahah theory in three concepts, namely, first: maslahah mu'tabara, the concept of maslahah whose existence does not conflict with the Qur'an and Hadith textually. Second: maslahah mursalah, this concept puts forward the principles of goodness and benefit in a matter even though it is not supported and may even be refuted by textual evidence in the Qur'an and Hadith.Third: maslahah mulghah, the concept of maslahah which contradicts textual evidence. From the perspective of its interests, there is something that is daruriyyah, where maslahah is very much needed for the benefit of the hereafter. There is also a hajiyyat, prioritizing maslahah to eliminate difficulties but not to the point of

\footnotetext{
${ }^{34}$ Ahmad Musțâfa al-Marāghi, Tafsir al-Marāghi (Beirut: Dârul Fiqr, 1973), p. 196.

${ }^{35}$ Muhammad Syahrur, Prinsip dan Dasar Hermeneutika HukumIslam Kontemporer, translation, Syahiron Syamsudin and BurhanudinDzikri (Yogyakarta: eISAQ Press, 2007), p.41.

${ }^{36}$ Nashr Farid M. Washil and Abdul Aziz M. Azzam, Qawâ’'id Fiqhiyyah, translation, Wahyu Setiawan (Jakarta: AMZAH, 2013), p.17.
} 
causing destruction. Meanwhile, the interests of tahsiniyyat serve to maintain honor. $^{37}$

The relationship with the legal product of the inheritance system in Islam outlined in the Qur'an Surah an-Nisâ/4: 11, in situations and conditions where people understand and are able to accept the inheritance system in Islam, then this verse applies textually.However, in the circumstances the inheritance process is carried out, causing disputes, which in turn occur disputes and even bloodshed among the heirs. There needs to be a solution that puts forward maslahah. This condition is what at-Tufi calls hajiyyat and may even be daruriyyah. If in this condition, the mappammana inheritance system is considered a transfer of property agreed upon between heirs and is able to avoid disputes, then this is not against inheritance law in Islam.

Likewise, the concept of changing Islamic law according to Ibn Qayyim alJauziyah puts forward the consideration of benefit. One aspect of his consideration is customs (urf), the tradition in which the law will be enforced.$^{38}$ Referring to the concept of al-Jauziyah, the mappammanatradition falls into the urf category as long as in practice it is agreed upon and creates maslahat.

The provision of people who are entitled to inheritance according to Islamic inheritance law is qat'iyah, which is a definite provision and cannot be changed. Thus, the heirs are qat'iyah whereas the process of distributing the inheritance may use the Islamic legal inheritance system or customary law such as mappammana, depending on the agreement between the heir and the person involved in the distribution of the inheritance.For this reason, they are welcome to choose the method of inheritance sharing with Islamic farid or with customary law which in the Buginese Bone tradition is called mappamana.

Therefore, the mappammana tradition as a process of sharing the inheritance of the Buginese community in Bone in Islamic inheritance law is allowed as long as it is mutually agreed upon and does not cause conflicts that can break the ties between families. Islamic sanity law is guided by the principles of fikhiyah, therefore the public is welcome to follow and use laws that bring benefit or use laws that are less harmful.

37 Idaul Hasanah, Konsep Maslahah Najamuddin al-Tufi dan Implementasinya, Ulumuddin Journal of Islamic Legal studies, Vol. 7, Number 1, 2011.

${ }^{38}$ Rizal Darwis, Pemikiran Ibnu Qyyim al-Jauziyah terhadap Faradigma Perubahan Hukum, Adzkiya: Jurnal Hukum dan Ekonomi Syariah, Vol. 5, Number 1, 2017. 


\section{CONCLUSION}

Mappammana is the transfer of property of objects by an heir, whether alive or dead, to a child or relative who is an heir. There are Mappammana which are general in nature, namely, pabbere and pappaseng, giving without any sacred value contained in the object which is used as maanaa.There also applies specifically, namely Ampik âle. It applies specifically because ampīkâle is a very sacred gift and is accompanied by a will. Based on Syahrur's hudud theory, at-Tufi's Maslahah, and alJauziayah's urf theory, the mappammana system implemented by most of the Buginese community in Bone is considered not to conflict with the Islamic inheritance system as long as its implementation is mutually agreed upon, which can lead to maslahat, maintain honor and keep away from disputes between fellow heirs.

\section{REFERENCES}

Abdurrahman.Kompilasi Hukum Islam. Jakarta: Akademika Pressindo, 2007.

Al-Marāghi, Ahmad Musțâfa.Tafsir al-Marāghi. Beirut: Dârul Fiqr, 1973.

al-Mehri, A. B. (Ed.). The Qur'ān: With Sūrah Introductions and Appendices: Saheeh International Translation. Maktabah Booksellers and Publishers, 2010.

Ash-Shabūni, Muhammad Ali.Al-mawaris fisySyari'ati Islâmiyyah'ala dhau' Al-kitâb was sunnah translated by: A. M. Baslamah.Pembagian Waris Menurut Islam. Jakarta: Gema Insani Press, 1996.

Darwis,Rizal. Pemikiran Ibnu Qyyim al-Jauziyah terhadap Faradigma Perubahan Hukum, Adzkiya Jurnal Hukum dan ekonomi Syariah, Vol. 5, Number 1, 2017.

Hasanah, Idaul. Konsep Maslahah Najamuddin al-Tufi dan Implementasinya,Ulumuddin Journal of Islamic Legal studies, Vol. 7, Number $1,2011$.

Hasnita Ira, Zubair Asni.Tinjauan Hukum Islam terhadap Ampikale dalam Sistem Kewarisan Masyarakat Bugis. Al-Syakhshiyyah Jurnal Hukum Keluarga Islam dan Kemanusiaan, Vol. 1, Number 2, 2019.

Lubis, Suhrawardi K. and Simanjuntak, Komis. Hukum Waris Islam. Jakarta: Sinar Grafika, 2008.

Muchlas, Imam. Waris Mewaris dalam Islam. Pasuruan: Garoeda Buana Indah, 1996. 
Nasution, Amin Husein. Hukum Kewarisan:Suatu Analisis Komparatif Pemikiran Mujtahid dan Kompilasi Hukum Islam. $3^{\text {rd }}$ Ed.; Jakarta: Rajawali Pers, 2014.

Qoyim, Ibnu.Adat dan Agama aalam Perkawinan dan Kewarisan pada Masyarakat Bugis.Jakarta: (PMB) LIPI, 2005.

Sabri, Muh.Persepsi Hukum Islam terhadap Sistem Kewarisan Berbasis Budaya pada Masyarakat Bugis Bone.Al-Risalah Jurnal Hukum Keluarga Islam (Akhwal alSyaksyiah), Vol. 3, 2017.

Syahrur, Muhammad.Prinsip dan Dasar Hermeneutika HukumIslam Kontemporer, translation, Syahiron Syamsudin and BurhanudinDzikri, Yogyakarta: eISAQ Press, 2007.

Syarifuddin, Amir.Garis-Garis Besar Fiqh. Jakarta: Prenada Media, 2005.

Washil, Nashr Farid M. and Azzam, Abdul Aziz M., Qawâ’id Fiqhiyyah, translation, Wahyu Setiawan,Jakarta: AMZAH, 2013.

Zubair, Asni.Aktualisasi Hukum Kewarisan Islam (Studi tentang Kesadaran Hukum Masyarakat di Desa Wollangi Kec. Barebbo terhadap Hukum Kewarisan Islam).AlRisalah Jurnal Hukum Keluarga Islam (Akhwal al-Syaksyiah), Vol. 3, 2017. 